\title{
ANALYSIS OF RADIOGRAPHIC BONE PARAMETERS THROUGHOUT THE SURGICAL LENGTHENING AND DEFORMITY CORRECTION OF EXTREMITIES
}

\author{
Nenad Atanasov, Anastasika Poposka, Milan Samardziski, Viktor Kamnar \\ University Orthopaedic Surgery Clinic, Medical Faculty, Ss. Cyril and Methodius University, Skopje, \\ R. Macedonia
}

Corresponding Author: Dr. Nenad Atanasov M.Sc., University Orthopedic Surgery Clinic, Medical Faculty, Ss. Cyril and Methodius University, Vodnjanska 17, 1000 Skopje, R. Macedonia, Tel: +389 (0)2 31476 26, E-mail: nenad.atanasov@yahoo.com

\begin{abstract}
:
Background: Radiographic examination of extremities in surgical lengthening and/or correction of deformities is of crucial importance for the assessment of new bone formation. The purpose of this study is to confirm the diagnostic value of radiography in precise detection of bone parameters in various lengthening or correction stages in patients treated by limb-lengthening and deformity correction.

Patients and Methods: 50 patients were treated by the Ilizarov method of limb lengthening or deformity correction at the University Orthopaedic Surgery Clinic in Skopje, and analysed over the period from 2006 to 2012. The patients were divided into two groups. The first group consisted of 27 patients with limb-lengthening because of congenital shortening. The second group consisted of 23 patients treated for acquired limb deformities. The results in both groups were received in three stages of new bone formation and were based on the appearance of 3 radiographic parameters at the distraction/compression site.

Results: The differences between the presence of all radiographic bone parameters in different stages of new bone formation were statistically signficant in both groups, especially the presence of the cortical margin in the first group (Cochran $\mathrm{Q}=34.43$, $\mathrm{df}=2, \mathrm{p}=0.00000$ ). The comparative analysis between the two groups showed a statistically significant difference in the presence of initial bone elements and cystic formations only in the first stage.

Discussion and Conclusions: Almost no statistical significance in the differences between both groups of patients with regard to 3 radiographic parameters in 3 stages of new bone formation, indicates a minor influence of the etiopathogenetic background on the new bone formation in patients treated by gradual lengthening or correction of limb deformities.
\end{abstract}

Key words: Limb lengthening, correction, radiography

\section{Introduction}

In the first half of the $20^{\text {th }}$ century, the prominent biomechanical centres in the world were intensifying their research activities in the field of the anatomical structure of bone. Most of the experiments in that period determined the pathways of cellular differentiation within the bone tissue influenced by mechanical stimulation. These new postulates are largely ba- sed on the results of the examinations of Gebhardt (1911), Steinmann (1919), Wurmbach (1928), etc. [1 \pm 3$]$, and particularly on the animal experiments of Beninghoff (1925) and Studitsky (1934) with artifficial mechanical strain on embryonic and mature bone $[4,5]$.

In the early fifties of the 20th century Gavril Abramovich Ilizarov brought up to date the stimulating process of new bone formation 
as well as regeneration of soft tissues caused by slow and gradual distraction. The basic principles of the Ilizarov method of distraction and compression on the segment are in fact the principles of the "law of strain of tension" with a gradual and permanent traction of supportive tissues. Besides limb lengthening, the controlled traction as well as compression on the segment results in metabolic activation of tissues and a stimulating effect on the proliferative and other biologic processes in the lengthened or compressed segment. These processes are closely related to the segmental blood supply, to the functional capacity of the tissues and to the local potential for a biological response of the exposed segment, e.g. extremity [6]. The external modular-ring fixator usually used in the distraction-compression method of Ilizarov is a remarkable innovation in the field of limb lengthening and the correction of limb deformities. Ilizarov especially emphasizes the importance of minimal operative damage to the anatomical structures and the importance of the load being transferred to the bone during postoperative treatment. Proper use of the device, as well as obeying the principles of the "law of strain of tension", allow early mobilization of the patient. The tensioning effect of the wires continuously loads the bone, unlike fixation with a plate or any other type of internal fixation. Bone-loading in an axial direction using this circular apparatus decreases the stress the bone is submitted to under normal conditions and offers moreover a possibility of versatile and flexible correction of various deformities of segments and whole extremities. The wires introduced into the bone can be fixed to the main and secondary supports of the fixator. An artificial mechanical action of slow and gradual distraction or compression of bony segments is possible in many different directions. During the treatment the tensioned wires ensure maximum stability and can be used to reduce bony malalignments [7] The stability of the external frame is of particular importance in maintenance of normal bone axes not only after the socalled corticotomy has been commenced, but throughout the whole process of surgical lengthening or correction till the moment of removal of the apparatus. Ilizarov defined corticotomy as a low-energy osteotomy of the cortex, with preservation of the local blood supply to both the periosteum and the medullary canal [8]. Performing a corticotomy enables gradual daily pulling apart of newly generated bone fragments as a basis for segmental lengthening and correction of various deformities of segments and whole extremities. Although the method of Ilizarov might be laden with numerous complications such as injuries to nerves and blood vessels, tendons or muscles, overtensioning of wires and cut-through phenomena, breaking or loosening of wires and bolts, sinking of olives on the points of contact with bone, severe joint contractures, subluxations and luxations, pin tract infections, etc. with consequences ranging from trivial to severe, it still remains a superior method in limb lengthening, simultaneous correction of angulatory, translational and rotational deformities, as well as in bone transports of intercalary segments in treatment of major bone and soft tissue defects [9]. Moreover, it can be used on the pelvic ring, as well as on all segments of upper and lower limbs with stabilization and/or correction of joint deformities and contractures. After the introduction of the method in various parts of the world in the last few decades, the external apparatus of Ilizarov has undergone an improving process in both the material and the design of the frame [10]. Several modifications of the original Ilizarov technique have been utilised leading thereby to a decrease of pin tract infection rate and significant improvement in the patient's comfort. Namely, although the Ilizarov apparatus employs tensioned wires for fixation, it has become common to supplement diaphyseal and sometimes even metaphyseal fixation with half-pins resulting in hybrid constructs. The advantages of these hybrid systems are the combination of a stable half-pin screw fixation and fixation with tensioned transfixing wires, thereby improving the versatility of the circular frame of Ilizarov and at the same time decreasing the dimension and weight of the fixator.

Radiographic examination of the segments of extremities involved in a process of surgical lengthening and/or correction of deformities is of crucial importance not only for precise determination of the distraction or correction rate, but for radiographic assessment of new bone 
formation in different stages of lengthening or correction, as well. (Fig. 1) The detection of early radiographic indicators of new bone formation such as solitary, confluent and linear radiographic shades on the native radiographs, as well as trabecular bone structure and a defined cortical margin in the latter stages of bone formation, enables a proper planning of artificial strain of tension or compression on the segment surgically treated according to the Ilizarov method [11].

The purpose of this study is to reaffirm the diagnostic value of the radiographic method in precise detection of the indicators of new bone formation in various lengthening or correction stages at the distraction or compression site in two different groups of patients from an etiopathogenetic point of view, treated by the method of Ilizarov.

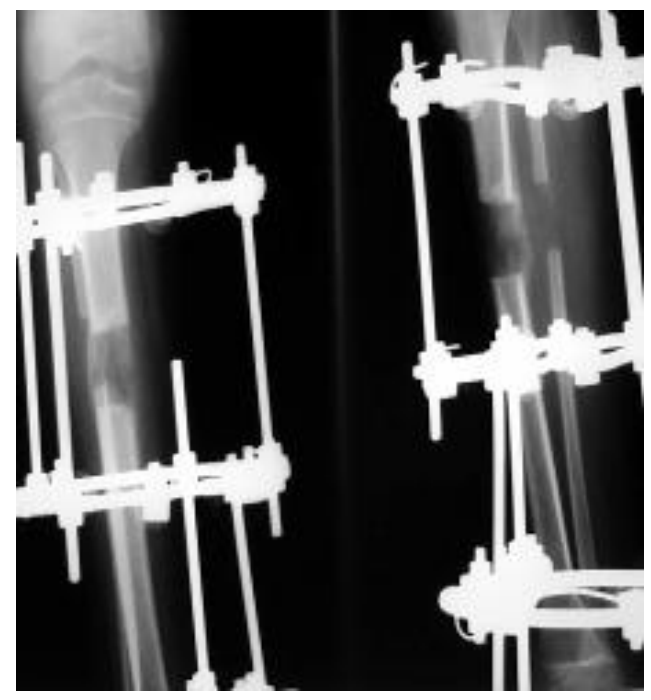

Figure 1 - Native radiograph of lower leg segment during a process of limb lengthening using the Ilizarov method. A visualization of early radiographic indicators of new bone formation is obvious at the distraction site

\section{Material and methods}

The clinical material consisted of 50 patients analysed in a prospective study, surgically treated by the Ilizarov method of limb lengthening or deformity correction at the University oOrthopaedic Surgery Clinic in Skopje, for a period of six years (2007-12). The patients were divided into two groups. The first group consisted of 27 patients who underwent a limb lengthening treatment according to the Ilizarov method because of segmental shortening caused by congenital anomalies of the limbs. 13 patients were males $(48.15 \%)$ and 14 females $(51.85 \%)$ in this group. The average age was 14.18. This group involved 41 separate bones on 27 analysed bone segments, 13 of which were lower legs, 11 thighs, 1 forearm and 2 arms. The second group consisted of 23 patients treated by the method of Ilizarov because of acquired limb deformities. The average age was 43.09, whereas the sex distribution revealed 14 males $(60.87 \%)$ and 9 females $(39.13 \%)$. In this group, the analysis was performed on 23 segments (8 lower legs, 5 thighs, 3 arms, 2 knee joints and 5 ankle joints) and 38 bones. In 7 of the patients in this group, a compressive arthrodesis was performed on an equal number of segments, e.g. joints, whereas the remaining 16 patients underwent a surgical correction of bone deformities or fixation and compression on the bone segments according to the Ilizarov method. The age difference between the two analyzed groups of patients presented a statistical significance. The mean age of the patients in the group with congenital anomalies on the limbs was highly significantly lower than the mean age of the patients in the group with acquired limb deformities $(p<0.001)$.

During the radiographic examination, special attention was paid to the following prerequisites:

1. Proper positioning of extremities necessary for receiving standard and correct results;

2. Standard and constant conditions for each examined segment, e.g. bone;

3. Maintenance of constant distance between the X-ray source and the examined segment in each stage of new bone formation;

4. The X-ray beam ultimately directed at the centre of the distraction/correction site;

5. X-ray examination performed in antero-posterior and medio-lateral projection;

6. High degree of visibility and clear presentation of the radiographic parameters. (Only obvious parameters with a high degree of clarity were taken into consideration during the process of analysing the results.)

The analysed results in the both groups were received in three different stages of new bone formation: (Fig. 2)

1. Stage of initial new bone formation; 
2. Stage of strain of tension/compression and advanced new bone formation;

3. Stage of mineralization, bone consolidation and remodelling.

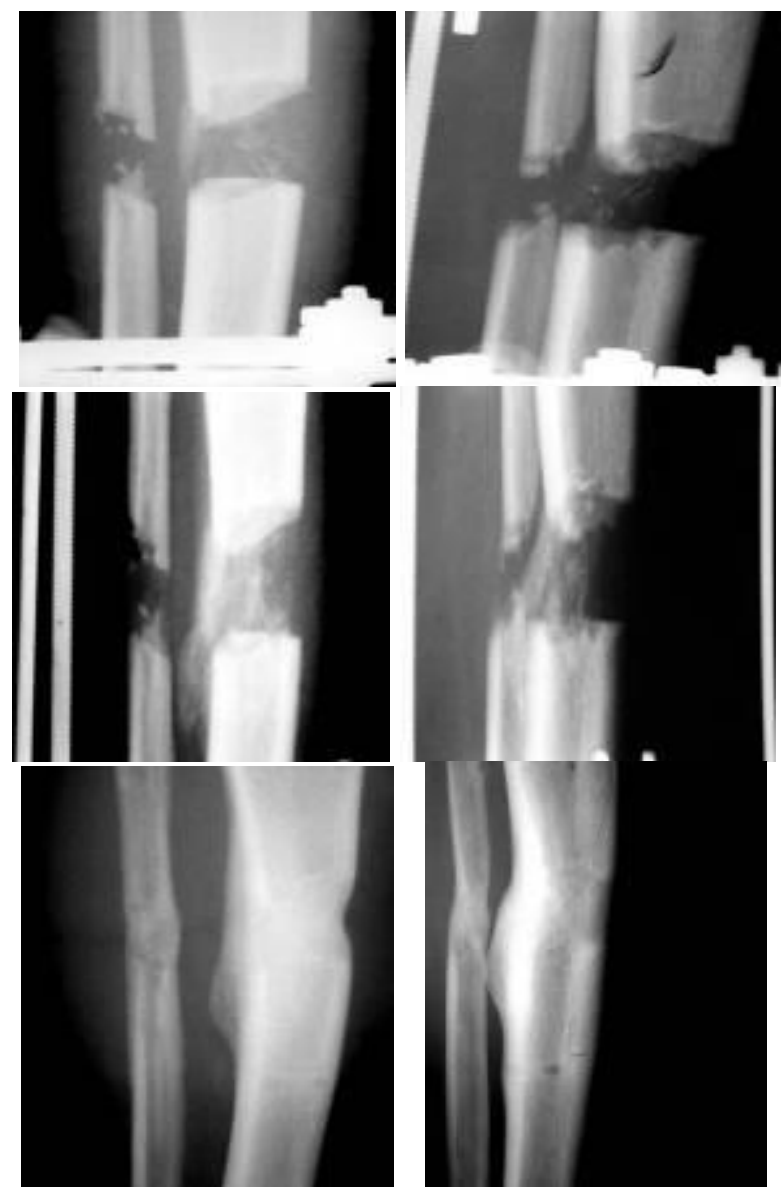

Figure 2 -Radiographic monitoring of new bone formation process in three stages in a patient with congenital lower leg shortening treated by the Ilizarov method of limb lengthening. The analysis was made in A-P and lateral plane (photo with magnification)

A comparative analysis was performed within each separate group of patients between the results received in the three different stages of new bone formation as well as between the two groups of patients, on the results recieved in the same stage of bone formation. The analysis was based on the appearance of 3 radiographic parameters - bone indicators at the distraction/compression site:

\section{Initial elements of new bone formation}

The radiographic presentation of initial elements of new bone formation depends on the stage of treatment by the method of Ilizarov. Therefore, in each lengthening/correction stage a domination of different radiographic mo- dalities is to be expected. Solitary and confluent indicators of new bone formation on the radiographs are typical for the stage of initial bone formation, whereas there are linear shades for the second stage of advanced bone formation. The presence of initial elements of new bone formation in the analysed bones is presented by the number of bones with registered initial elements of new bone formation compared to the whole number of analysed bones in the study for each stage of bone formation separately.

\section{Cystic formations}

The presence of cystic formations on the site of osteogenesis is of particular importance, since it indicates an initial crisis in new bone formation, and is often thought to be related to venous or lymphatic congestion. Although cystic degeneration of the gap can be demonstrated easily with either quantitative computed tomography or ultrasonography, the radiographic determination of a "cystic zone of new bone formation" at the distraction/compression site remains at a high level of importance because it often opens the possibility of immediate changes in the rhythm and dynamics of the surgical lengthening or compression on the segment. The radiographic presence of cysts in the analysed bones in our study is presented by the number of bones with registered cysts on X-rays compared to the whole number of analysed bones in the study for that radiographic parameter in each stage of bone formation separately.

\section{Cortical margin}

The radiographic presentation of a cortical margin is one of the characteristics of the consolidation and remodelling stage, which proceeds simultaneously with the process of intensive mineralization of the osteoid matrix in the zone of new bone formation. The radiographic presence of a cortical margin in the analysed bones is presented by the number of bones with a registered cortical margin on X-rays compared to the whole number of analysed bones in the study for that radiographic parameter in each stage of bone formation separately.

The statistical analysis on the received data using the radiographic method of examination in this study was based on the statistic program SPSS for Windows 13.0. 
Qualitative data were presented with absolute and relative numbers, whereas quantitative data were presented as mean and SD.

The significance of the differences between the analysed variables in the two different groups was determined using T-test for independent samples, Pearson Chi-square test and Cochran's Q test. The level of significance was $\mathrm{p}<0.05$.

\section{Results}

A total number of 50 patients were analyzed in this study. 27 were males and 23 females. They were divided into two groups. The first group consisted of 27 patients treated with limb lengthening by the Ilizarov method because of congenital segmental shortening, and the second with fixation, compression or deformity correction because of acquired segmental deformities, consisting of 23 patients. The comparative analysis in the first group was based on the results of the radiographic examination of 27 segments and 41 bones, whereas in the second group the number of segments was 23 with 38 bones. From the point of view of the presence of the above-mentioned three radiographic indicators of new bone formation, the results in each of the three stages of new bone formation for each of the two separate groups of patients were the following:

In the first group, the initial elements of new bone formation were presented in 15 of 41 bones on the radiographic findings in the first stage of new bone formation, which means $36.59 \%$. In the second stage the presence of these parameters was in 38 out of 41 analysed bones in this group of patients, or $92.68 \%$, whereas in the third stage the percentage was $26.83 \%$, or the initial elements were registered in 11 out of the whole number of 41 analysed bones in this examined group. The differences between the presence of initial radiographic elements in different stages of new bone formation were presented as statistically signficant (Cochran $\mathrm{Q}=34.43$, df $=2, \mathrm{p}=0.00000$ ) (Table 1).

The presence of cystic formations in the zone of newly formed bone was in one bone on the radiographic findings in the first stage of new bone formation which means $2.44 \%$. In the second stage the presence of these parame- ters was in 12 out of 41 analysed bones in this group of patients, or $29.27 \%$, whereas in the third stage the percentage was $7.32 \%$, or the cysts were registered in three out of the whole number of 41 analysed bones in this examined group. The differences between the presence of cystic formations in different stages of new bone formation were presented as statistically signficant $($ Cochran $=15.85, \quad \mathrm{df}=2, \mathrm{p}=0.00036)$ (Table 2)

Table 1

Initial radiographic elements in the three stages of new bone formation in the group of patients with congenital shortening

\begin{tabular}{|l|c|c|c|}
\hline $\begin{array}{l}\text { Initial } \\
\text { elements of } \\
\text { new bone } \\
\text { formation }\end{array}$ & \multicolumn{4}{|c|}{ Stage } \\
\hline No & I & II & III \\
\hline Yes & $26(63.41 \%)$ & $3(7.32 \%)$ & $30(73.17 \%)$ \\
\hline Total & $15(36.59 \%)$ & $38(92.68 \%)$ & $11(2683 \%)$ \\
\hline
\end{tabular}

Table 2

Cystic formations in the three stages of new bone formation in the group of patients with congenital shortening

\begin{tabular}{|l|c|c|c|}
\hline $\begin{array}{l}\text { Cystic } \\
\text { formations }\end{array}$ & I & II & III \\
\hline No & $40(97.56 \%)$ & $29(70.73 \%)$ & $38(92.68 \%)$ \\
\hline Yes & $1(2.44 \%)$ & $12(29.27 \%)$ & $3(7.32 \%)$ \\
\hline Total & 41 & 41 & 41 \\
\hline
\end{tabular}

The radiographic appearance of the cortical margin was presented in 10 of 41 bones in the first stage of new bone formation which means $24.39 \%$. In the second stage the presence of this parameter was in 30 out of 41 analysed bones in this group of patients, or $73.17 \%$, whereas in the third stage the percentage was $100 \%$, or the cortical margin was registered in all of the analysed bones in the first group. The differences between the presence of this radiographic parameter in different stages of new bone formation were presented as statistically signficant $($ Cochran $=47.81, \mathrm{df}=2, \mathrm{p}=0.000000)($ Table 3).

In the second group of patients, the initial elements of new bone formation were presented in 31 of 38 bones on the radiographic fin- 
dings in the first stage of new bone formation, which means $81.58 \%$. In the second stage the presence of these parameters was in 33 out of 38 analysed bones in this group of patients, or $86.84 \%$, whereas in the third stage the percentage was $36.84 \%$, or the initial elements were registered in 14 out of the whole number of 38 analysed bones in this examined group. The differences between the presence of initial radiographic elements in different stages of new bone formation were presented as statistically signficant $($ Cochran $=23.36, \mathrm{df}=2, \mathrm{p}=0.000008)$.

Table 3

Cortical margin in the three stages of new bone formation in the group of patients with congenital shortening

\begin{tabular}{|l|l|l|l|}
\hline $\begin{array}{l}\text { Cortical } \\
\text { margin }\end{array}$ & I & \multicolumn{2}{|c|}{ Stage } \\
\hline No & $31(75.61 \%)$ & $11(26.83 \%)$ & 0 \\
\hline Yes & $10(24.39 \%)$ & $30(73.17 \%)$ & $41(100 \%)$ \\
\hline Total & 41 & 41 & 41 \\
\hline
\end{tabular}

The presence of cystic formations in the zone of newly formed bone in the second group was in 10 bones on the radiographic findings in the first stage of new bone formation which means $26,31 \%$. In the second stage the presence of these parameters was in 12 out of 38 analysed bones in this group of patients, or 31, $58 \%$, whereas in the third stage the percentage was $5,26 \%$, or the cysts were registered in two out of the whole number of 38 analysed bones in this examined group. The differences between the presence of cystic formations in different stages of new bone formation were presented as statistically signficant $($ Cochran $=16.8$, $\mathrm{df}=2, \mathrm{p}=0.000225$ ).

The radiographic appearance of the cortical margin was presented in 11 of 38 bones in the first stage of new bone formation, which means $28.95 \%$. In the second stage the presence of this parameter was in 26 out of 38 analysed bones in this group of patients, or $68.42 \%$, whereas in the third stage the percentage was $100 \%$, or the cortical margin was registered in all of the analysed bones in the second group. The differences between the presence of this radiographic parameter in different stages of new bone formation were presented as statistically signficant (Cochran $=40.67$, $\mathrm{df}=2, \mathrm{p}=0.00000)($ Fig. 2)

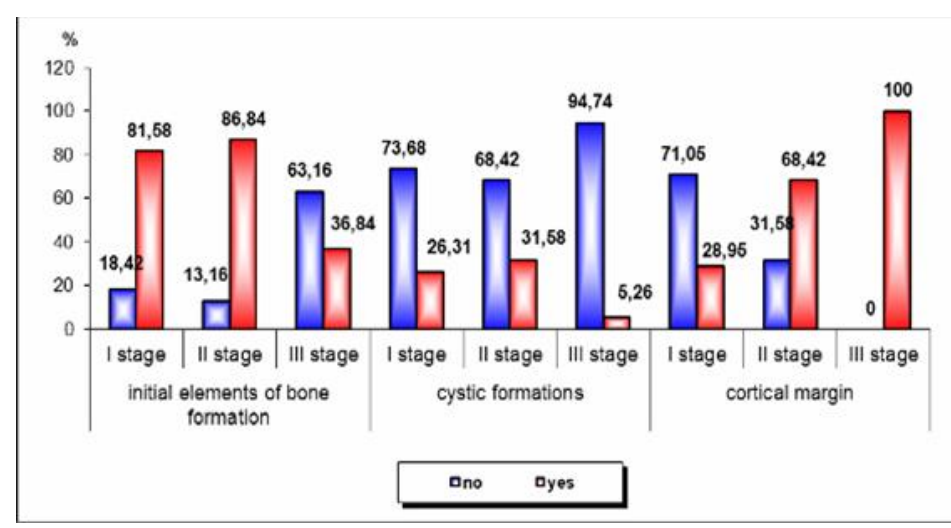

\section{Figure 3 - Distribution of radiographic parameters of new bone formation in three stages of correction in the group of patients with acquired deformities}

The comparative analysis between the two groups of patients revealed the following results:

The presence of initial elements of newly formed bone showed a significant difference between the two groups of patients only in the first stage of new bone formation. In the first group initial elements of new bone formation wereregistered in 15 out of 41 patients and the percentage was $36.59 \%$, whereas in the second group initial elements of new bone formation were registered in 31 out of the whole number of 38 patients in this group $(81.58 \%)$, a difference which presented a statistical significance according to the Pearson Chi-square test (16.4144, df $=1, p=0.000051$ ) (Table 4). In the other two stages no significant difference was registered. 
Table 4

$$
\begin{gathered}
\text { Comparative analysis of presence of initial elements } \\
\text { in the first stage of bone formation in two groups } \\
\text { of patients }
\end{gathered}
$$

\begin{tabular}{|l|c|c|c|}
\hline $\begin{array}{l}\text { Initial } \\
\text { elements } \\
\text { in the first } \\
\text { stage of } \\
\text { bone } \\
\text { formation }\end{array}$ & $\begin{array}{l}\text { Group with } \\
\text { congenital } \\
\text { shortening }\end{array}$ & $\begin{array}{c}\text { Group with } \\
\text { acquired } \\
\text { deformities }\end{array}$ & Total \\
\hline No & $26(63.41 \%)$ & $7(18.42 \%)$ & 33 \\
\hline Yes & $15(36.59 \%)$ & $31(81.58 \%)$ & 46 \\
\hline Total & 41 & 38 & 79 \\
\hline
\end{tabular}

The number of bones in which cystic formations were registered was similar in both the groups in all stages of new bone formation except the first stage, in which a statistically significant difference was registered (one bone out of 41 in the first group vs 10 bones out of 38 in the second group) (Pearson Chi-square: 9.38089, $\mathrm{df}=1, \mathrm{p}=0.002193$ ) (Table 5).

Table 5

Comparative analysis of presence of cystic formations in the first stage of bone formation in two groups of patients

\begin{tabular}{|l|c|c|c|}
\hline $\begin{array}{l}\text { Cystic } \\
\text { formations } \\
\text { in the first } \\
\text { stage of bone } \\
\text { formation }\end{array}$ & $\begin{array}{l}\text { Group with } \\
\text { congenital } \\
\text { shortening }\end{array}$ & $\begin{array}{c}\text { Group with } \\
\text { acquired } \\
\text { deformities }\end{array}$ & Total \\
\hline No & $40(97.56 \%)$ & $28(73.68 \%)$ & 68 \\
\hline Yes & $1(2.44 \%)$ & $10(26.32 \%)$ & 11 \\
\hline Total & 41 & 38 & 79 \\
\hline
\end{tabular}

The presence of a cortical margin did not show a significant difference between the two groups in any of the three stages of new bone formation.

\section{Discussion}

The compression-distraction method of Ilizarov means a revolution in the field of limb lengthening and deformity correction of segments and extremities. Bone fixation using a circular frame and transfixing tensioned wires provides not merely multiplanar stability during the lengthening process, but a possibility of flexible correction of various isolated and combined complex deformities on certain seg- ments as well. Nowadays, the tendency of accomplishing the Ilizarov apparatus is obvious through use of so-called hybrid systems for external fixation, with a combination of standard elements from the basic set of Ilizarov on the one hand, with typical elements of some other external fixation systems on the other hand. In this manner, a simultaneous use of tensioned wires with half pins is not a rare occasion anymore. The reasons for the use of these types of combined external fixation are not determined only by the caution for the anatomic structures on the segments, e.g. extremities during the surgical insertion, but are frequently based on the results of serious biomechanical analysis of the effects of external fixation on different segments of the extremities. Nevertheless, lengthening a long bone by cutting it surgically and then pulling apart the bone fragments using the method of "strain of tension" is a process laden with numerous complications. Apart from bone infections, neurological disorders, joint contractures, etc., the greatest threats are surely either poor bone consolidation and remodelling of the newly generated bone, or its premature healing, both due to inadequate rate, frequency or rhythm of surgical distraction. This leads to fractures, distortion of the axis, or lack of osseous consolidation of the newly formed bone [12]. In order to reduce the number of such complications, a permanent monitoring of the entire process is necessary, from the initial moment of treatment until the distraction apparatus is removed. In this manner, plain radiography is considered as one of the most useful imaging modalities for evaluation of the bony alignment and the extent of osseous production, especially in the latter stages of new bone formation. Native radiographs, although later than diagnostic ultrasonography, still allow visualization of the primordial hazy densities within the site of bone formation. The progression of bone healing from the central zone of collagenous growth to the more peripheral columns of mineralized bone results in a distinctive radiographic appearance, especially in lengthening procedures. Some experimental studies indicate that if the density of tissue mineralization appears attenuated centrally and the central radiolucent zone exceeds eight millimeters in thickness, then the rate of distraction may be too fast and should be adjusted. However, if the thickness of the central radiolucent zone decreases 
to less than two millimeters and the external surface of the forming bone appears to be fusiform, then the rate of distraction may be too slow and should be accelerated in order to avoid premature consolidation which ineviatably produces many complications in the further treatment [13]. The diagnostic value of native radiography can be estimated by precise determination of the time needed for bone formation at metaphyseal compared with the diaphyseal sites on an experimental model. The metaphyseal sites demonstrated bone formation and remodelling earlier on the X-rays, with an over-all bone-healing index of 22 days per centimeter of new bone compared with 26.5 days per centimetre at the diaphyseal sites, which is similar to our clinical experience [13]. The superiority of diagnostic radiography over other diagnostic methods of evaluation of newly formed bone at the distraction or compression site is most evident in the stages of bone mineralization and remodelling, due to the possibilities of the radiographic method for visualization of the trabecular bone structure, as well as to the advantage of the observation of the whole bone and especially the zone of new bone formation in many different planes and projections. Therefore, using native radiography as a method of choice in the monitoring of the whole new bone formation process, enables not only an optimal dynamics of surgical correction, but leads to a proper decision when to remove the external stabilizer and additionally to protect the segment with a plaster cast for approximately one month longer.

The analysis of our material was performed on the results received from two different groups of patients, from the point of view of the type of surgical procedure using the method of Ilizarov, as well as from point of view of the etiopathogenetic pattern of the treated deformities. Additionally, in each of both groups, an analysis was performed on the results considering the number of bones in which each of the three radiographic bone parameters was registered at every stage of bone formation separately. This comparative analysis revealed statistically significant differences in different stages of bone formation regarding the presence of all the examined parameters of new bone formation, e.g. initial elements of new bone formation, cystic formations, as well as a cortical margin at the site of bone formation. This difference was registered in both groups of patients separately, in all stages of new bone formation. The results of the comparative analysis between the two groups showed a statistically significant difference towards the presence of initial elements of newly-formed bone in the first stage of new bone formation. A statistically significant difference was detected considering the presence of cystic formations at the site of bone formation between the two groups of patients in the first stage of bone formation, as well. All the other stages presented no statistically significant difference between the two groups of patients, from the point of view of the presence of the above-mentioned examined parameters of new bone formation.

\section{Conclusion}

The radiographic method of evaluation of newly-formed bone at the distraction/compression site in patients treated by limb lengthening and/or correction of deformities is of great importance in terms of estimation of the stage of new bone formation, as well as in terms of planning the regimen of surgical lengthening or correction. There is an obvious difference between the radiographic presence of bone parameters in different stages of new bone formation in the group of patients with congenital limb length discrepancies as well as in the group of patients with acquired limb deformities. A rare statistical significance between the differences in both groups of patients in this study in terms of the presence of the three radiographic parameters in each of the three stages of new bone formation, indicates a minor influence of both the etiopathogenetic background and the type of surgical correction on the course of the new bone formation process in patients treated by surgical lengthening or gradual correction of limb deformities.

\section{REFERENCES}

1. Gebhardt W. Diskussion zum Vortrag J. Schaffer: Trajektorielle Strukturen im Knorpel. Verh. anat. ges. Jena, 1911; 25: 169.

2. Steinmann F. Lehrbuch der funktionellen Behandlung der Knochenbrüche und Gelenkverletzungen. Enke, Stuttgart, 1919.

3. Wurmbach H. Histologische Untersuchungen über die Heilung von Knochenbrüchen bei Säugern. Z. wiss. zool. 1928; 132: 200-256. 
4. Benninghoff A. Der funktionelle Bau des Hyalinknorpels. Erg. Anat. Entwickl. - Gesch. 1925; 26: 1.

5. Studitsky A.N. Experimentelle Untersuchungen über die Histogenese des Knochengewebes. Z. Zellforsch. 1934; 20: 658-676.

6. Ilizarov GA. The tension-stress effect on the genesis and growth of tissues: The influence of stability of fixation and soft tissues preservation. Clin. Orthop. 1989; 238: 249-281.

7. Ilizarov GA. The tension-stress effect on the genesis and growth of tissues: The influence of the rate of frequency of distraction Clin. Orthop. 1989; 239: 263-285.

8. Ilizarov A.G. Results of clinical tests, an experience obtained from the clinical use of the set of Ilizarov compression-distraction apparatus. Med. Export, Moscow, 1976.

\section{Резиме}

$$
\begin{array}{lllll}
\text { ен Д } & \text { т } & \text { сов, н ст сик } & \text { опоск }, \\
\text { ил н } & \text { м рџиски, иктор мн }
\end{array}
$$

Ј3У Универзитетска клиника за ортопедски болести, Медицински факултет, Универзитет „Св. Кирил и Методиј“, Скопје, Р. Македонија

овед: Радиографското испитување на екстремитетите при хируршкото лекување и/или корекција на деформитетите е од големо значење во процената на новото коскено создавање. Целта на овој труд е да ја потврди дијагностичката вредност на радиографијата при прецизното одредување на коскените параметри во различни стадиуми на издолжување или корекција на деформитети на екстремитетите.

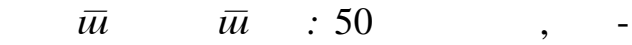
тирани со издолжување или корекција на деформитети според методот на Илизаров на Универзитетската клиника за ортопедски болести во Скопје во периодот од 2006 до 2012 година, беа подложени на анализа во оваа студија. Пациентите беа поделени во две групи. Првата група се
9. Saleh, M., \& Scott, B. W. Pitfalls and complications in leg lengthening: The Sheffield experience. Seminars in Orthopaedics. 1992; 7(3), 207-222.

10. Speigelberg B, Parratt T, Dheerendra SK, Khan WS, Jennings R, Marsh DR. Ilizarov principles of deformity correction. Annals of the Royal College of Surgeons in England, 2010; 92(2): 101-105.

11. Starr KA, Fillman R, Raney EM. Reliability of radiographic assessment of distraction osteogenesis site. J Pediatr Orthop. 2004; 24: 26-29.

12. Valentin Antoci, MD, PhD, Craig M. Ono, MD, Valentin Antoci, Jr., PhD, and Ellen M. Raney, MD. Pin-Tract Infection During Limb Lengthening Using External Fixation. Am J Orthop. 2008; 37(9): E150E154.

13. Aronson J. Experimental and clinical experience with distraction osteogenesis. Cleft Palate Craniofac J. 1994; 31: 473-481.

состоеше од 27 пациенти со издолжување на екстремитетите поради вродено скратување. Втората група вклучи 23 пациенти, третирани поради стекнати деформитети на екстремитетите. Резултатите од двете групи испитаници беа добиени во три стадиуми на ново коскено создавање, а се базираа на појавувањето на три радиографски параметри во просторот на дистракција/компресија.

езулй $\bar{u} и:$ Разликите во присуството на сите радиографски коскени параметри во различните стадиуми на коскено создавање покажаа статистичка значајност кај двете групи, особено кај присуството на кортикалниот раб во првата група (Cochran $\mathrm{Q}=34,43$, df $=2, \mathrm{p}=0$, 00000). Компаративната анализа меѓу двете групи покажа статистички значајна разлика во присуството на почетни коскени елементи и цистични формации само во првиот стадиум.

искусиј и з клучоци: Ретката статистичка значајност во разликите меѓу двете групи пациенти во поглед на присуството на трите радиографски параметри во трите стадиуми индицира минорно влијание на етиопатогенетската основа врз новото коскено создавање кај пациенти лекувани со постепено хируршко издолжување или корекција на деформитети на екстремитетите.

лучни зборов и: издолжување екстремитети, корекција, радиографија. 